\title{
The Effect of Intensive and Extensive Focus on Form on EFL Learners' Written Accuracy
}

\author{
Massoud Rahimpour \\ University of Tabriz, Tabriz, Iran \\ Email: Rahimpour2011@gmail.com \\ Asghar Salimi \\ University of Tabriz, Tabriz, Iran \\ Email: Asgharsalimi356@gmail.com \\ Farahman Farrokhi \\ University of Tabriz, Tabriz, Iran \\ Email: ffarrokhi20@yahoo.co.uk
}

\begin{abstract}
A number of Second Language Acquisition researchers argue that since focus on form facilitates second language development, therefore special attention to focus on form in the case of adult learners seems to be necessary. This area of research has been one of the hotly-debated issues in SLA literature. The main purpose of the present quasi-experimental study is to investigate the effects of intensive and extensive focus on form instructions on EFL learners' written accuracy. For the purpose of the study 40 learners of English at pre-intermediate level were chosen randomly as the participants of the study and assigned into two groups of experimental which received different types of instruction for 2 months. A narrative task and written production focused and unfocused tasks were employed to collect data from the participants. The collected written data was quantified in terms of the accuracy measure introduced by Ellis (2008).T-test was employed as the statistical means of analysis. The results of the study revealed significant differences between the performances of two groups in terms of the accuracy in focused written production task. The study carries significant implications for second language teachers, SLA researchers as well as task designers.
\end{abstract}

Index Terms - focus on form, intensive focus on form, extensive focus on form, accuracy, task, noticing hypothesis

\section{INTRODUCTION}

When second or foreign language learners speak or write, the fluency, accuracy, and complexity of their utterances will be affected in different linguistic domains by many factors such as experience of the teacher, anxiety of L2 learners, planning time, topic familiarity, nature of the task, proficiency of the learners, task type, task condition, task structure, and very importantly the degree of noticing and attention to forms (Rahimpour, 1999, 2008).

Although there has been a plethora of research supporting the effectiveness of form-focused instruction as corrective feedback in general (Gu, 2007; Ellis, 1999, 2003, 1994, 2005, 2008; Rahimpour, 1999, 2001; Rahimpour and Salimi, 2010; Farrokhi and Rahimpour, 2011; Khatib and Alizedeh, 2012; Asadollahfam, et al, 2012; Bichener, et al, 2005; Jernigum, 2012; Chandler, 2003; Falhasiri, et al, 2011), there have been very few studies regarding the role of the nature of focus on form and the degree of drawing learners' attention on EFL learners' written performance. The main purpose of the present experimental study is to investigate the effect of intensive and extensive focus on form on L2 learners' written performance in terms of accuracy.

\section{LITERATURE REVIEW}

Mastering the grammar of a second language and being able to correctly implement this knowledge is a demanding and challenging task to accomplish. Due to this reason, most of EFL/ESL learners often encounter difficulty in expressing themselves accurately in oral or written productions. They may have a good knowledge of language structure and usage but might have difficulty in using that declarative knowledge in practice, thus unable to convert it into procedural one. As Khatib and Alizadeh (2012) argue this makes grammar instruction open to research. Furthermore, the paradoxical research results (Gu, 2007; Noris and Ortega, 2000) and many other researchers makes this area a burgeoning area of investigation, specially within task-based approach over the past two decades.

\section{A. Focus on Form}

Focus on form has been variously defined by different scholars in the field of SLA.

Long (1983) defines it as 
Focus on FORM... overtly draws learner's attention to linguistic elements, as they arise incidentally in lessons whose overriding focus is on meaning or communicative (Long, 1983, p.45-6)

Long and Robinson (1998) defines focus on form in an operational way as follows:

Focus on Form often consists of occasional shift of attention to linguistic code features by the teacher or one or more students triggered by perceived problem with comprehension or production (Long and Robinson, 1998, P: 23).

In line with Schmidt's Noticing Hypothesis (1990, 1994, 2001), Skehan (1996) supports the role of focus on form in assisting the learners to link declarative to their procedural and communicative use of the form structure. He suggests that

Learners benefit from some type of explicit instruction prior to the activity to help them activate their knowledge of TL structures and facilitate awareness of the forms they will encounter (Skehan, 1996, p: 46).

Schmidt (1990, 2001) also argues that L2 learners must efficiently notice and be aware of the features of input in order for intake and learning to be possible. He also mentions attention as a necessary construct for understanding every aspect of SLA (cited in Rahimpour and Salimi, 2010).

\section{B. Focus on Form and Its Types}

Focus on Form is usually compared with focus on Forms. Long (2000) defines focus on forms as a traditional teaching approach in which teachers present the learners with pre-selected and sequenced linguistic items. Van Patten (2002) criticized traditional instruction of focus on forms as "putting the cart before the horse" (p. 795), explaining that it generally intends to manipulate output as a means of changing the nature of the developmental system. Ellis (2001) and Farrokhi and Rahimpour (2011, p. 151) categorize focus on form into three types of focus on forms, incidental, and planned focus on form. As it was mentioned, focus on forms is nothing but the traditional structurally designed syllabus in which language is considered as a system and the primary focus is on language structure and forms (Long, 1996, Asadollahfam, et al, 2011). Planned focus on form involves the use of communicative tasks designed to elicit preselected forms in a meaning-focused context. The third type of F-O-F is the incidental form in which attention is paid to linguistic elements as they arise incidentally in the course of instruction. This type of focus on form aims at eliciting general samples of the language, rather than specific forms. This type of instruction according to Ellis, Basturkmen, and Loewen (2002) involves the use of unfocused communicative tasks.

\section{Extensive and Intensive Corrective Feedback and the Gap in Literature}

Corrective feedback has recently attracted many researchers' interest in SLA literature. On theoretical grounds, there are different views on the role of naturalistic SL acquisition; Krashen (1985) believes that corrective feedback is not only useless but also harmful since it disrupts the flow of discourse and communication. However, there are many researchers who claim that corrective feedback is effective and necessary and has a facilitative role in SL development (Schmidt, 1990; Long, 1996; Swain, 1998). These researchers argue that noticing involved in focus on form help learners to recognize the gap between interlanguage and target language. Van Patten (2002) and Ellis (2009) also support the role of corrective feedback in the form of negotiation for meaning in making the learners notice their errors and creating form-meaning connections and helping SL acquisition.

What remains missing in the literature is the effect of the degree of attention on foreign language learners (intensive and extensive focus on form) on L2 learners' written production (Ellis, 2008).

Ellis (2003) defines extensive focus on form as drawing learners' attention on the whole range of linguistic items involving various grammatical, lexical, and phonological non-targets like forms produced by the learner. Intensive focus on form, however, involves drawing learners' attention repeatedly to specific language items, particularly a grammatical one. Bearing the gap in literature in mind, specifically, investigation of types of focus on form (intensive/extensive) could contribute to SLA literature theoretically and practically.

\section{RESEARCH QUESTION AND HYPOTHESES}

This study aims at answering the following research question and the hypotheses in relation to written corrective feedback:

$R Q$ : What are the effects of intensive and extensive focus on form on L2 learners' written accuracy?

HO: There is not any significant difference between intensive and extensive focus on form and L2 learners' written accuracy.

H1: Learners receiving intensive focus on form strategies will outperform learners receiving extensive focus on form in terms of accuracy in written production.

\section{Methodology}

\section{A. Participants}

The participants of the study were 40 pre-intermediate learners of English affiliated to Iran National Language Institute, West Azerbaijan, Iran. The syllabus in this institute is a meaning-based one that provides students with different opportunities to take part in communicative activities (Interchange series, Richards, et al, 2005). They were 
selected randomly on the basis of their performances on a test (Oxford Proficiency Test, 2004). They had the same experience of language learning background for 4-5 years in the same institute. The participants were chosen out of 80 homogeneous learners- the same level.

\section{B. Procedure}

Having been divided into 2 groups of intensive and extensive groups, the learners received treatment in the form of extensive and intensive form-focused instruction for one semester on the forms focused in units1-5 of interchange Book 2. The participants in intensive group received corrective feedback from the teacher on the tasks assigned by the teacher to the learners on pre-selected language forms (past tense) covered by each lesson. The corrective feedback given to L2 learners was in the form of direct error correction form. The other group (extensive) received treatment in the form of $\mathrm{CF}$ on the written assignments for not only forms covered, but also on any lexical and grammatical errors. A narrative written task, as well as written production focused and unfocused tasks were employed as the means of data collection for post-test and delayed post-test, respectively. Accuracy measure for the accuracy of written narrative task was errorfree T-units per T-units (Ishikawa, 2006; Rahimpour, 1999; Salimi, et al, 2011). The delayed post-test was administrated after two weeks.

\section{DATA ANALYSIS AND RESUlts}

T-test was employed as the statistical means of analysis for comparing the means of 2 groups in narrative task, as well as written production task.

Table 1 shows the results of descriptive statistics for the accuracy of written narrative task.

TABLE 1

DESCRIPTIVE STATISTICS FOR THE ACCURACY OF WRITTEN NARRATIVE TASK IN INTENSIVE AND EXTENSIVE FOF GROUPS

\begin{tabular}{lllll} 
Grouping & N & Mean & Std. Deviation & Std. Error Mean \\
\hline Accuracy Extensive Witten Task & 20 & .6790 & .11107 & $\mathbf{. 0 2 4 8 4}$ \\
\hline Accuracy Intensive Written Task & 20 & .7025 & .13653 & .03053
\end{tabular}

Figure 1 vividly shows the means of accuracy of written narrative task in intensive and extensive groups.

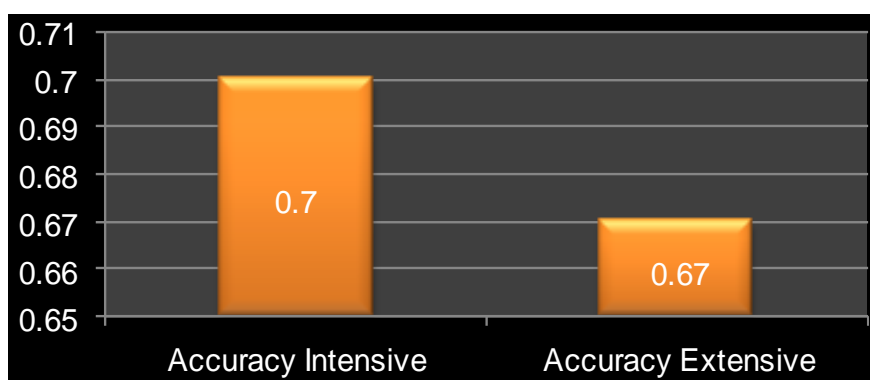

Figure 1 Comparison of the Means of Accuracy of Written Narrative Task in Intensive and Extensive FOF Groups

According to the figure, learners receiving intensive form-focused instruction outperformed learners who received extensive focus on form strategies in terms of their accuracy in written narrative task. Independent samples T-test was employed as the statistical means of analysis. The results are shown in the following table.

TABLE 2.

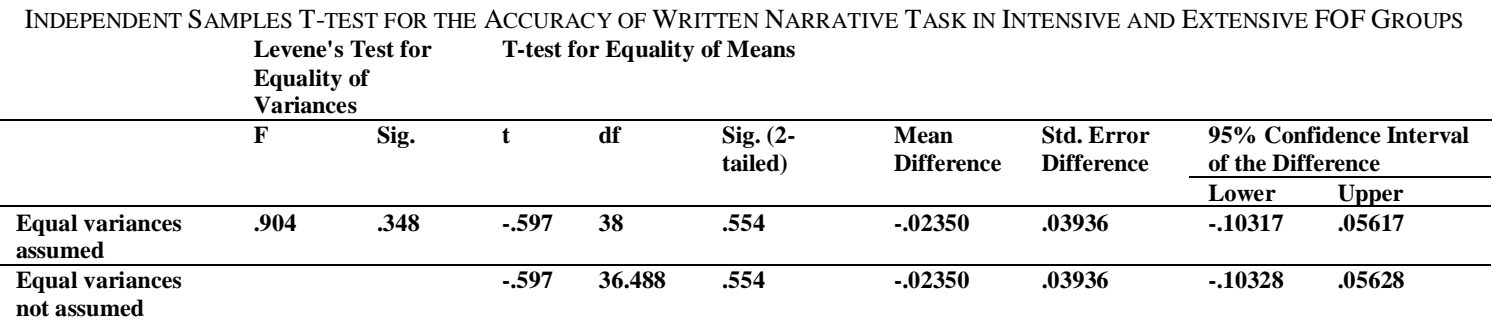

According to table 2, although intensive group outperformed extensive group; however, the result of inferential statistics of Independent Samples T-test revealed no significant difference between the accuracy of two groups. As a result, the null hypothesis stating that "there is not any significant difference between intensive and extensive focus on form and L2 learners' written accuracy" is confirmed. A delayed written production post-test including focused and unfocused was also employed to test the effect of durability of the instruction. 
TABLE 3.

DESCRIPTIVE STATISTICS FOR THE ACCURACY OF WRITTEN PRODUCTION FOCUSED TASK IN INTENSIVE AND EXTENSIVE FOF GROUPS

\begin{tabular}{lllll} 
Grouping & N & Mean & Std. Deviation & Std. Error Mean \\
\hline Accuracy Intensive Focused & 20 & 14.35 & 1.725 & .386 \\
\hline Accuracy Extensive Focused & 20 & 12.55 & 2.012 & .450
\end{tabular}

Table 3 shows the results of descriptive statistics for the accuracy of written production focused task.

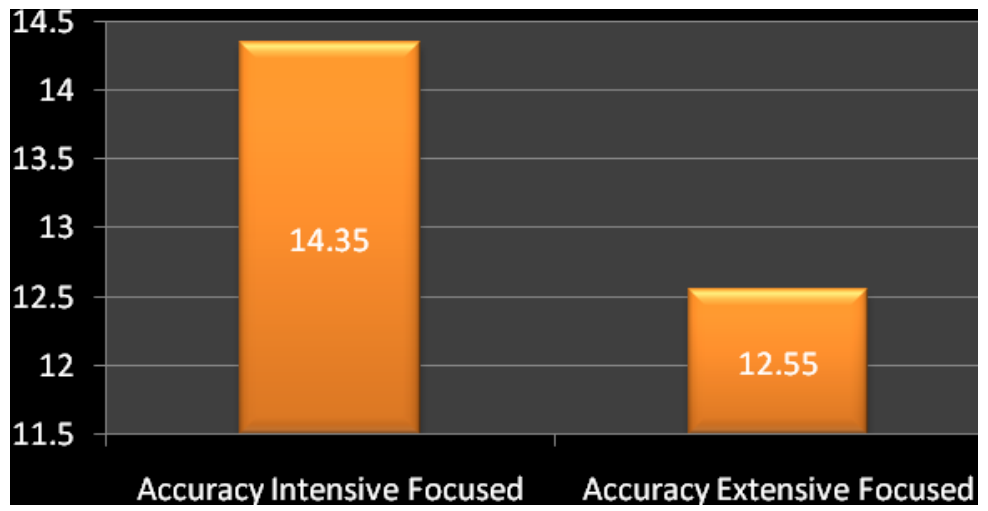

Figure 2 Comparison of the Means of Accuracy of Written Production Focused Task in Intensive and Extensive FOF Groups

Figure 2 also shows the means of accuracy in focused task for both groups. It is clear that participants receiving intensive form-focused instruction outperformed extensive group in terms of accuracy in written production focused task.

TABLE 4.

INDEPENDENT SAMPLES T-TEST FOR THE ACCURACY OF WRITTEN PRODUCTION FOCUSED TASK IN INTENSIVE AND EXTENSIVE FOF GROUPS Levene's Test T-test for Equality of Means for Equality of Variances

\begin{tabular}{|c|c|c|c|c|c|c|c|c|c|}
\hline & \multirow[t]{2}{*}{$\mathbf{F}$} & \multirow[t]{2}{*}{ Sig. } & \multirow[t]{2}{*}{$\mathbf{t}$} & \multirow[t]{2}{*}{ df } & \multirow[t]{2}{*}{$\begin{array}{l}\text { Sig. (2- } \\
\text { tailed) }\end{array}$} & \multirow[t]{2}{*}{$\begin{array}{l}\text { Mean } \\
\text { Difference }\end{array}$} & \multirow[t]{2}{*}{$\begin{array}{l}\text { Std. Error } \\
\text { Difference }\end{array}$} & \multicolumn{2}{|c|}{$\begin{array}{l}95 \% \text { Confidence Interval } \\
\text { of the Difference }\end{array}$} \\
\hline & & & & & & & & Lower & Upper \\
\hline Equal variances assumed & .467 & .499 & 2.793 & 37 & .008 & 1.613 & .578 & .443 & 2.783 \\
\hline $\begin{array}{l}\text { Equal variances not } \\
\text { assumed }\end{array}$ & & & 2.787 & 36.302 & .008 & 1.613 & .579 & .440 & 2.787 \\
\hline
\end{tabular}

Table 4 shows the results of Independent Samples T-test for the accuracy of written production focused task for both groups. The results of statistical analysis show that there is significant difference between means of two groups in terms of the accuracy in focused task. As a result, intensive form-focused instruction was much more effective than intensive form-focused instruction in the delayed post-test. Thus, our null hypothesis is rejected and the hypothesis stating that "learners receiving intensive focus on form strategies will outperform learners receiving extensive focus on form in terms of accuracy in written production" is confirmed.

TABLE 5.

DESCRIPTIVE STATISTICS FOR THE ACCURACY OF WRITTEN PRODUCTION UNFOCUSED TASK IN INTENSIVE AND EXTENSIVE FOF GROUPS

\begin{tabular}{llll} 
& Mean & Std. Deviation & N \\
\hline Accuracy Intensive Unfocused & 12.40 & 1.569 & 20 \\
\hline Accuracy Extensive Unfocused & 13.35 & 1.663 & 20
\end{tabular}

Table 5 shows the descriptive statistics of groups in intensive and extensive in terms of accuracy in unfocused task in the delayed post-test. 


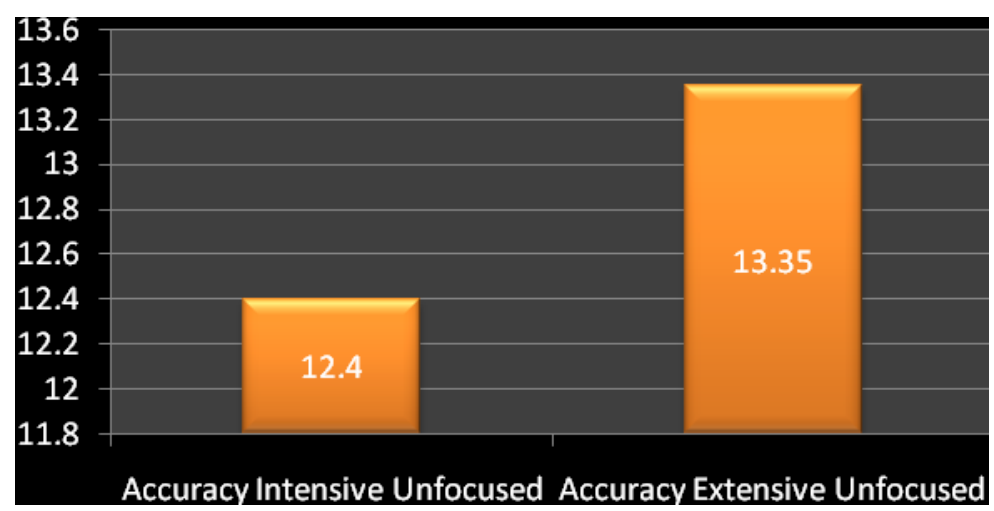

Figure 3. Comparison of the Means of Accuracy of Written Production Unfocused Task in Intensive and Extensive FOF Groups

Figure 3 shows that learners receiving extensive form-focused instruction outperformed learners receiving intensive form-focused instruction in terms of accuracy in written production unfocused task in the delayed post-test.

TABLE 6.

INDEPENDENT SAMPLES T-TEST FOR THE ACCURACY OF WRITTEN PRODUCTION UNFOCUSED TASK IN INTENSIVE AND EXTENSIVE FOF GROUPS

\begin{tabular}{|c|c|c|c|c|c|c|c|c|c|}
\hline & \multicolumn{2}{|c|}{$\begin{array}{l}\text { Levene's Test for } \\
\text { Equality of Variances }\end{array}$} & \multicolumn{7}{|c|}{ T-test for Equality of Means } \\
\hline & \multirow[t]{2}{*}{$\mathbf{F}$} & \multirow[t]{2}{*}{ Sig. } & \multirow[t]{2}{*}{$\mathbf{t}$} & \multirow[t]{2}{*}{ df } & \multirow[t]{2}{*}{$\begin{array}{l}\text { Sig. (2- } \\
\text { tailed) }\end{array}$} & \multirow[t]{2}{*}{$\begin{array}{l}\text { Mean } \\
\text { Difference }\end{array}$} & \multirow[t]{2}{*}{$\begin{array}{l}\text { Std. Error } \\
\text { Difference }\end{array}$} & \multicolumn{2}{|c|}{$\begin{array}{l}\text { 95\% Confidence } \\
\text { Interval of the } \\
\text { Difference }\end{array}$} \\
\hline & & & & & & & & Lower & Upper \\
\hline $\begin{array}{l}\text { Equal variances } \\
\text { assumed }\end{array}$ & .101 & .752 & -1.858 & 38 & .071 & -.950 & .511 & -1.985 & .085 \\
\hline Equal variances & & & -1.858 & 37.873 & .071 & -.950 & .511 & -1.985 & .085 \\
\hline
\end{tabular}

not assumed

According to table 6, no significant difference was found between the performances of two groups in written production unfocused task in delayed post-test. As a result, the null hypothesis stating that "there is not any significant difference between intensive and extensive focus on form and L2 learners' written accuracy" is confirmed.

\section{DisCUSSION}

Regarding our hypothesis claiming that there is a significant difference between intensive form-focused instruction group's performance and extensive form-focused instruction group's performance, the results of statistical analysis for written narrative task revealed that there was no significant difference between the performances of the two groups statistically. However, learners who received intensive form-focused instruction did slightly better than those who received extensive form-focused instruction. The findings of the study are in line with the findings of Truscott (1996) and Ferris (1999). According to Truscott (1993) the type of feedback provided didn't have any significant effect on the accuracy. Also, Ferris (1999) suggests that the effectiveness of written corrective feedback depends on the feature itself whether it is treatable or not. The rejection of the hypothesis does not mean that form-focused instruction was ineffective. Rather, both types of instruction were effective when Pearson correlation for both groups was computed.

The findings of the study also ran against the findings of Bichener et al (2005) who found that type of written corrective feedback had significant effect on the accuracy in intensive way when separate linguistic categories were utilized. According to them, the provision of full, explicit written feedback, together with individual conference feedback resulted in significantly greater accuracy when different linguistic forms (past tense and the definite article) were used in new pieces of writing. Their findings were in line with our proposed hypothesis. They also found that providing learners with corrective feedback would help learners notice the difference between their errors and the corrections they receive. Noticing such differences is widely accepted in SLA literature as crucial for uptake and longterm retention (Schmidt, 1990, 1994). The findings of the study also ran against the findings of Rahimpour \& Salimi (2010) who found significant difference between the performances of learners who received implicit (extensive) and explicit (intensive) instructions. The results showed that learners who received extensive instructions outperformed learners who received intensive instruction.

Considering the results of statistical analysis for the delayed post-test in focused and unfocused task, it was revealed that there was significant difference between the accuracy of two groups in focused task. That is, learners who received intensive form-focused instruction outperformed learners who received extensive from-focused instruction statistically. The findings of the study are in line with the findings of Bichener et al (2005), Norris and Ortega (2000), Falhasiri et al (2011), Sheen (2007), and Chandler (2003). Norris and Ortega (2000) examined the effectiveness of L2 instruction by conducting a meta-analysis of experimental and quasi-experimental studies. The results of their study proved some positive evidence for the superiority of explicit, intensive instruction over implicit, extensive instruction and evidence 
for the durability of L2 instruction. They also indicated that "a focus on form and a focus on forms are equally effective" (P: 501). The results of the study of Falhasiri et al (2011) also proved that explicit, deductive, and intensive instruction would decrease the error frequency of the students, specifically interlingual errors. Chandler (2003) studied the effect of different types of corrective feedback on L2 learners' accuracy and fluency in writing. The results proved that all types of corrective feedback were effective; however, intensive correction was best for producing accurate revisions. This high rate of accuracy in intensive group can be attributed to the nature of the drawing learners' attention repeatedly to the same structure and as a result more consciousness of the linguistic feature would occur which would facilitate greater attention to form resulting in greater accuracy.

\section{Pedagogical Implications}

The present study carries important implications for SLA literature, SLA researchers, second and foreign language teachers, and syllabus and task designers. For SLA literature, the study can contribute to the theory of SLA by understanding more about the nature of the processes of second language acquisition. For SLA researchers, as Hyland and Hyland (2006) argues:

While feedback is a central aspect of L2 writing programs across the world, the research literature has not been equivocally positive about its role in L2 development, and teachers often have a sense they are not making use of its full potential (p. 83).

Furthermore, the inability and inadequacy of communicative teaching alone to promote high level of accuracy in learners is a fact in EFL contexts. Therefore, task-based language teaching is particularly suitable for formal instruction. Designing such tasks (focused/unfocused) would release more traditionally oriented non-native speaker teachers from the requirement to lead communicative activities in target language. Task designers can also take into account the degree of the attention necessary for performing a task. In line with the findings of the study, the importance of the study is attributed to the fact that it lends additional support to the importance attributed to the incorporation of focus on form as well as focus on forms into meaning-oriented instruction especially in EFL contexts.

\section{REFERENCES}

[1] Asadollahfam, H., Kuhi, D., Salimi, A., and Mirzaei, Sh. (2012). Effect of Incidental Focus on Form and Scaffolding on SL learners' accuracy. Procedia- Social and Behavioral Sciences (In press).

[2] Bichener, J., young, Y., and Cameron, D. (2005). The effect of different types of corrective feedback on ESL student writing. Journal of Second Language Writing, 14. 191-205.

[3] Chandler, j. (2003). The efficacy of various kinds of error feedback for improvement in the accuracy and fluency of L2 student writing. Journal of Second Language Writing, 12. 267-296.

[4] Ellis, R. (1994). The study of second language acquisition. Oxford: Oxford University Press.

[5] Ellis, R (1999). Input-based approaches to teaching grammar: A review of classroom-oriented research. Annual Review of Applied Linguistics 19, 64-80.

[6] Ellis, R. (2001). Investigating form-focused instruction. In R. Ellis (Ed.), Form-focused instruction and second language learning (pp. 1-46). Malden, MA: Black well publishers.

[7] Ellis, R. (2003). Task-based language learning and teaching. Oxford: Oxford University Press.

[8] Ellis, R (Ed.) (2005). Planning and task performance in a second language. Amsterdam: John Benjamins.

[9] Ellis, R. (2008). Typology of written corrective feedback. ELT Journal; doi: 10. 1093/elt/ccn023.

[10] Ellis, R. (2009). Task-based language teaching: Sorting out the misunderstandings. International Journal of Applied Linguistics Vol. 19, 3. pp: 229-246.

[11] Ellis, R., Basturkmen, H., and Loewen, S. (2002). Doing focus on form. System, 30, 419-432.

[12] Ferris, D. (1999). The case for grammar correction in L2 writing classes: a response to Truscott (1996). Journal of Second Language Writing, 8. 1-10.

[13] Falhasiri, M., Tavakoli, M., Hasiri, F., and Mohammadzadeh, A. (2011). The effectiveness of explicit and implicit corrective feedback on interlinguagl and intralinguagl errors: A case of error analysis of students' compositions. English Language Teaching, Vol. 4. No.3. 251-264.

[14] Farrokhi, F. \& Rahimpour, M. and Papi, Z. (2011). Incidental focus on form techniques in Iranian EFL classroom: A comparison between expert and novice teachers. English Language Teaching, Vol. 1, No. 1. 150-157.

[15] Gu, X. (2007). Focus on form or focus on forms: Which method is more effective? Teachers College, Colombia University Working papers in TESOL \& Applied Linguistics. Vol. 7, No. 1. 1-2.

[16] Hyland, K. and Hyland, F. (2006). Feedback on second language students' writing. Language Teaching, 39. 83-101.

[17] Ishikawa, T. (2006). The effects of task complexity and language proficiency on task- based language performance. The Journal of Asia TEFL, 3(4), 193-225.

[18] Jernigun, J. (2012). Output and English as a second language pragmatic development: The effectiveness of output- focused video-based instruction. English Language Teaching, Vol. 5, No. 4. 2-14.

[19] Khatib, M. and Alizadeh, M. (2012). Output tasks, noticing, and learning: Teaching English past tense to Iranian EFL learners. English Language Teaching, Vol. 5. No.4. 173-186.

[20] Krashen, S.D. (1985). The input hypothesis. London: Longman.

[21] Long, M.H., (1983). Does second language instruction make a difference? A review of the research. TESOL Quarterly, 17(3), 359-382. 
[22] Long, M. H. (1996). The role of linguistic environment in second language acquisition. In W. C. Ritchie\& T. K. Bhatia (Eds.). Handbook of second language acquisition. (pp.413-463). San Diego; Academic Press.

[23] Long, M.H., (1998). 'Focus on form in task-based language teaching'. University of Hawai'i Working papers in ESL 16: 35-49.

[24] Long, M. (2000). Focus on form in task-base language teaching. In R. Lambert \& E. Shohamy (Eds.), Language Policy and Pedagogy: Essays in Honor A. Ronald Walton (179-192). Philadelphia: John Benjamins.

[25] Long, M.H. and Robinson, P. (1998). "Focus on form: Theory, research, and practice", in focus on form in classroom Second Language Acquisition, C, Doughty and J. Williams, Eds. Cambridge: CUP, (pp. 15-42).

[26] Norris, J. M., and Ortega, L. (2000). Effectiveness of L2 instruction: A research synthesis and quantitative meta-analysis. Language Learning, 50, 417-528.

[27] Rahimpour, M. (1999). Task complexity and variation in interlanguage. In N. O. Jungheim\&P. Robinson (Eds.), Pragmatic and pedagogy: proceeding of the3rd pacific Second Language Research Forum (pp.115-134). Tokyo, Japan: Pac LRF.

[28] Rahimpour, M. (2001). The acquisition of L2 in instructed and naturalistic situation. Journal of Faculty of Letters and Humanities. University of Tabriz, 44. 10-39.

[29] Rahimpour, M. (2008). Implementation of task-based approaches to language teaching. Pazhuhesh-e-Zabanha-ye Khareji Journal, University of Tehran, 41, 45-61.

[30] Rahimpour, M. and Salimi, A. (2010). The impact of explicit instruction on foreign language learners' performance. ProcediaSocial and Behavioral Sciences, 2, 1740-1746.

[31] Richards, J. C. (2005). New Interchange 2 3rd Edition. Cambridge University Press.

[32] Salimi, A., Dadashpour, S., Asadollahfam, H. (2011). The effect of task complexity on EFL learners' written performance. Procedia- Social and Behavioral Sciences, 29, 1390-1399.

[33] Schmidt, R. (1990). The role of consciousness in second language learning. Applied Linguistics, 11, 129-158.

[34] Schmidt, R. (1994). "Implicit Learning and the cognitive unconscious: of artificial grammars and SLA". In N.C. Ellis (Ed.), Implicit and explicit learning of Languages (pp. 165-209). San Diego, CA: Academic Press.

[35] Schmidt, R. (2001). Attention, In P. Robinson (Ed.), Cognition and second Language instruction (pp. 3-32). Cambridge: Cambridge University Press.

[36] Sheen, Y. (2007). The effect of focused written corrective feedback and language aptitude on ESL learners' acquisition of articles. TESOL Quarterly, Vol. 41, No. 2. 255-283.

[37] Skehan, P. (1996). A framework for the implementation of task-based instruction. Applied Linguistics, 17(1), 38-62.

[38] Swain, M. (1998). 'Focus on form through conscious reflection' in C. Doughty \& J. Williams (Eds.). pp: 64-81.

[39] Truscott, J. (1996). The case against grammar correction in L2 writing classes. Language Learning, 46. 327-369.

[40] Van Patten, B. (2002). Processing instruction: An update. Language Learning, 52. 755-803.

[41] Washington. P. C. (1982). Communicate What You Mean. Prentice Hall

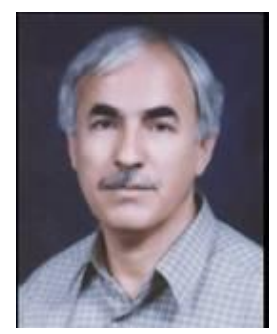

Massoud Rahimpour is an Emeritus Professor and has been the Honorary Research Consultant The University of Queensland, Brisbane, Australia holding M.A in teaching English from the University of Oklahoma City in USA and Ph. D in applied linguistics from The University of Queensland in Australia. He lectures in the areas of SLA, syllabus design and TESOL methodology at the University of Tabriz. Dr. Rahimpour has presented and published several books and tens of papers in international conferences and journals. He has also supervised many M.A and Ph. D theses. His main areas of interest are task-based language teaching and learning, second language acquisition, syllabus design, and research methodology. He is currently teaching in The University of Queensland in Australia.

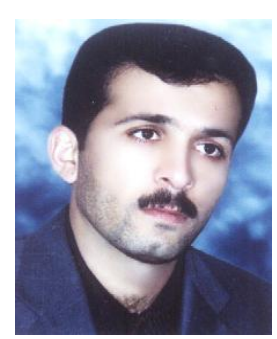

Asghar Salimi is a PhD candidate in applied linguistics at the University of Tabriz. He has been teaching English for over 10 years. He is currently a faculty member of Maragheh University. He has presented more than ten papers in different national and international conferences in different countries. His main areas of interest are task-based learning and teaching, syllabus design, and Second Language Acquisition (SLA).

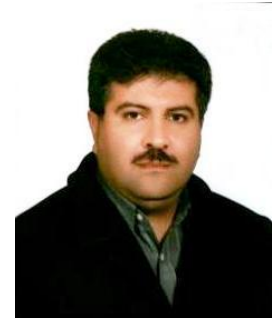

Farahman Farrokhi was born in Iran in 1967. He received his Ph.D. degree in English language teaching from University of Leeds, England in 2002. He received his M.A. degree in English language teaching from Tarbiat Modarres University, Tehran, Iran in 1993, and he also got the B.A. degree in English translation from AllamehTabatabaii University, Tehran, Iran in 1990. He is Dean of the Faculty of Persian Literature and Foreign Languages at University of Tabriz, and currently he is an associate professor at the University of Tabriz. His research interests include classroom discourse analysis, EFL teachers' perceptions of different feedback types, negative and positive evidence in EFL classroom context, language testing, Task-based teaching, and syllabus design. 